\section{The Radiological and Clinical Outcomes of Routinely Performed Second Head Computed Tomography in Children with Mild Traumatic Brain Injury}

\author{
Hafif Travmatik Beyin Yaralanması olan Çocuklarda \\ Rutin Olarak Çekilen İkinci Bilgisayarlı Beyin \\ Tomografisinin Radyolojik ve Klinik Sonuçları
}

\begin{abstract}
Aim: In this study, we aimed to assess how the routine use of a second head computed tomography (CT) scan contributed to therapeutic approach in children diagnosed with mild traumatic brain injury (TBI)

Methods: The retrospective study included children with mild TBI who had traumatic lesions on initial head CT and underwent a second CT scan as performed routinely at our pediatric emergency department between August 2010 and August 2014. Patient data (age and sex, mechanism of trauma, symptoms, physical examination findings, results of the first and second head CT scans, time between the two scans, and medical and surgical treatments) were recorded.

Results: A total of 113 patients met the inclusion criteria and $57.5 \%$ of them were male. The median patient age was 28 (interquartile range: 6.5-80) months. Seventy-two (63.7\%) patients were asymptomatic on admission and there was no finding on physical examination in 54 (47.8\%) patients. Of all traumatic lesions, $64.9 \%$ were linear skull fracture, $13.7 \%$ subdural hematoma, $13 \%$ contusion, 3.8\% subarachnoid hemorrhage, 3\% epidural hematoma, 0.8\% intraparenchymal hemorrhage, and $0.8 \%$ depressed skull fracture. The routine second head CT scans were performed after $11 \pm 2.5$ hours and revealed progression in $6.2 \%$ of the patients. No subsequent change in medical treatment or neurosurgical intervention occurred.
\end{abstract}

Conclusion: Although the progression rate in routinely repeated CT at our emergency department was $6.2 \%$, there was no change in the medical and neurosurgical interventions performed.

Keywords: children; head computed tomography; traumatic brain injury

\section{Öz}

Amaç: Bu çalıșmada ilk bilgisayarlı beyin tomografisinde (BBT) hafif travmatik beyin yaralanması (TBY) olan çocuklarda rutin olarak çekilen ikinci BBT'nin tedavi yaklașımına katkısını değerlendirmek amaçlanmıștır.

Yöntem: Retrospektif çalıșmamız Ağustos 2010-Ağustos 2014 döneminde pediyatrik acil servisimizde hafif TBY'li cocuklar arasından ilk BBT'sinde travmatik lezyon görülen ve rutin olarak ikinci kez BBT çekilen hastalarla gerçekleștirildi. Hasta verileri (yaș ve cinsiyet, travma mekanizması, belirtiler, fizik muayene bulguları, ilk ve ikinci BBT bulguları, iki BBT arasındaki süre, medikal ve cerrah tedaviler) kaydedildi.

Bulgular: Calıșma, dahil edilme kriterlerini sağlayan ve \%57,5'i erkek olan toplam 113 hasta içerdi. Ortanca hasta yașı 28 (çeyrekler arası aralık: 6,5-80) ay idi. Hastaların 72'si (\%63,7) hastaneye kabul sırasında asemptomatikti ve $54(\% 47,8)$ hastada bir fizik muayene bulgusu yoktu. Travmatik lezyonların \%64,9'u lineer kafatası fraktürü, \%13,7'si subdural hematom, \%13'ü kontüzyon, \%3,8'i subaraknoid kanama, \%3'ü epidural hematom, \%0,8'i intraparankimal kanama, \%0,8'i çökme fraktürü

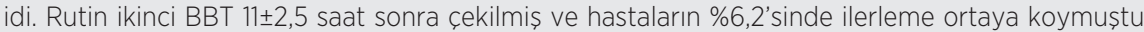
Sonrasında medikal ya da nörocerrahi tedavide bir değișiklik olmamıștı.

Sonuç: Acil servisimizde rutin olarak tekrarlanan BBT'de ilerleme oranı \%6,2 olmakla birlikte uygulanan medikal ve nörocerrahi tedavilerde bir değișiklik olmamıștır.

Anahtar Sözcükler: bilgisayarlı beyin tomografisi; çocuklar; travmatik beyin yaralanması
Anil Er', Aykut Caglar', Fatma Akgul', Emel Ulusoy', Murat Duman', Durgul Yilmaz

1 Division of Pediatric Emergency Medicine, Department of Pediatrics, Faculty of Medicine, Dokuz Eylül University

Received/Gelis : 11.02.2021 Accepted/Kabul: 29.05.2021

DOI: 10.21673/anadoluklin.878492

Corresponding author/Yazıșma yazarı Durgul Yılmaz

Dokuz Eylül Üniversitesi Tıp Fakültesi, Çocuk Sağ|ığı ve Hastalıkları Anabilim Dalı, Cocuk Acil Bakım Bilim Dalı, 35340 İzmir, Turkey E-mail: durgul.ozdemir@deu.edu.tr

\section{ORCID}

Anil Er: 0000-0002-2805-5420

Aykut Caglar: 0000-0002-2805-5420 Fatma Akgul: 0000-0002-6503-2279

Emel Ulusoy: 0000-0002-2827-1553 Murat Duman: 0000-0001-6767-5748 Durgul Yilmaz:0000-0002-4944-2913 


\section{INTRODUCTION}

Pediatric traumatic brain injury (TBI) is a global health problem as an important cause of disability and death $(1,2)$. The majority of emergency department admissions due to pediatric head trauma consist of cases of mild TBI, which is defined as a Glasgow Coma Scale (GCS) score of 13-15 within the first 24 hours $(1,3)$. Head computed tomography (CT) is a rapid and reliable tool for the diagnosis of TBI requiring immediate intervention (4,5). Although the Pediatric Emergency Care Applied Research Network (PECARN) decision rules for initial head CT have been widely implemented, physicians have great difficulty in ordering repeated head CT in children with mild TBI whose initial head CT has revealed a traumatic lesion (4).

Age-related structural and developmental features complicate the proper evaluation of children in follow-up $(4,6,7)$. Neurological assessment is a major challenge due to difficulties in comprehension and cooperation, especially in preverbal children $(7,8)$. Accordingly, in TBI concerns about progression and the consequent need for neurosurgical intervention result in physicians scheduling a second head CT routinely (9-11). However, the data on effects of early neurosurgical intervention on outcomes of pediatric TBI are inadequate $(7,12)$. Furthermore, repeated CT is accompanied by other problems such as increased exposure to ionizing radiation, increased healthcare costs, and loss of health workforce $(7,10,13,14)$. As children are more sensitive to radiation and have a greater risk of radiation-induced malignancies due to longer life expectancy, a CT dose reduction without compromising diagnostic ability and the selective use of CT are crucial $(15,16)$. Despite all these considerations, there have been limited data on the use of repeated head CT in children with mild TBI, and determination of patients who could clinically benefit from a second head CT remains controversial $(5,8,10-12,17,18)$. Thus, in this study we aimed to evaluate the diagnostic and clinical value of second head CT results and their contribution to medical treatment and/or neurosurgical interventions in children with mild TBI who had a traumatic lesion on the initial head CT. We hypothesized that the results of second head CT would lead to no significant change in medical and/or neurosurgical interventions.

\section{MATERIALS AND METHODS}

The retrospective cohort study was performed in the pediatric emergency department (PED) of the Dokuz Eylül University between August 2010 and August 2014. We included children with mild TBI (with a GCS score of 13 to 15) who had a positive initial head CT scan and subsequently underwent a second CT scan as part of routine clinical practice. A positive head CT scan was defined as the presence of lesions related to head trauma, such as skull fracture (linear, depressed or skull-base), epidural hematoma (EDH), subdural hematoma (SDH), contusion, intraparenchymal hemorrhage (IPH), and subarachnoid hemorrhage (SAH). We excluded newborns as well as patients who had penetrating or non-accidental injury, neurological disorder, hereditary or acquired coagulopathy, bone metabolism disorder, or a history of neurosurgery, who required neurosurgical intervention before a second head CT scan, and who were admitted more than 24 hours after trauma.

During the study period, our PED had approximately 60.000 annual admissions and five pediatric residents participated in the management of patients under the supervision of two academic staff. Also, two pediatric emergency fellows joined the staff after March 2013. The initial head CT was performed based on the PECARN decision rules (4), but there was no protocol for the use of a second head CT scan in our PED.

A blinded chart reviewer obtained demographic and clinical data from the electronic medical records and excluded the patients with incomplete data. The form used abstracted data on patient age and sex, trauma mechanism, admission symptoms, physical examination findings, initial and second head CT findings, time between the two scans, and medical treatments (anti-epileptic drugs, hypertonic saline, mannitol) and neurosurgical interventions (craniotomy, external ventricular drainage). The mechanism of trauma was classified as fall, pedestrian struck, motor vehicle accident, bicycle-related injury, and struck by an object. The patients were divided into two groups: preverbal $(<2$ years) and verbal ( $\geq 2$ years).

The primary outcomes studied were progression in the second head CT scan and a subsequent requirement 
Table 1. Demographic and clinical characteristics of the study groups

\begin{tabular}{|c|c|c|c|}
\hline & Preverbal $(n=44)$ & Verbal $(n=69)$ & $p$ \\
\hline \multicolumn{4}{|l|}{ Sex, n (\%) } \\
\hline Male & $25(56.8)$ & $40(58.0)$ & \multirow{2}{*}{0.904} \\
\hline Female & $19(43.2)$ & $29(42.0)$ & \\
\hline \multicolumn{4}{|l|}{ Trauma mechanism, $\mathbf{n}(\%)$} \\
\hline Fall & $37(84.1)$ & $47(68.1)$ & \multirow{5}{*}{0.038} \\
\hline Head struck by an object & $7(15.9)$ & $7(10.1)$ & \\
\hline Pedestrian struck by vehicle & - & $8(11.6)$ & \\
\hline Motor vehicle accident & - & $6(8.7)$ & \\
\hline Bicycle collision & - & $1(1.4)$ & \\
\hline \multicolumn{4}{|l|}{ Symptoms on admission, $\mathbf{n}(\%)$} \\
\hline Asymptomatic & $34(77.2)$ & $38(55.1)$ & \\
\hline Symptomatic & $10(22.8)$ & $31(44.9)$ & \\
\hline Vomiting & $7(63.4)$ & $12(36.4)$ & \\
\hline Loss of consciousness & $4(36.6)$ & $12(36.4)$ & $0.017^{*}$ \\
\hline Headache & - & $5(15.1)$ & \\
\hline Amnesia & - & $4(12.1)$ & \\
\hline Findings on physical examination, $\mathbf{n}(\%)$ & & & \\
\hline No finding & $13(26.5)$ & $41(59.4)$ & \\
\hline Finding & $31(73.5)$ & $28(40.6)$ & \\
\hline Scalp hematoma & $31(86.1)$ & $24(75.0)$ & $0028^{\dagger}$ \\
\hline Scalp laceration & $4(11.1)$ & $8(25.0)$ & 0.028 \\
\hline Palpable skull fracture & $1(2.8)$ & - & \\
\hline
\end{tabular}

"Comparison of symptomatic and asymptomatic patients

${ }^{\dagger}$ Comparison of patients with and without physical examination findings

for medical or neurosurgical treatment. Second head CT findings were defined as "no progression" if there was no new lesion or the size, number and severity of the initial lesion was the same or improved, and "progression" if there was a new lesion or the size, number, or severity of the initial lesion had increased. All scan findings were reported by radiologists under the supervision of the same academic pediatric radiologist.

\section{Statistical analysis}

All statistical analyses were performed using the SPSS (v. 22.0) software package (IBM Corp., Armonk, NY). Descriptive statistics were presented as mean and standard deviation (SD) or median and interquartile range (IQR) for quantitative data. Categorical data were expressed as rates. The difference between the rates was analyzed using the chi-square test or Fisher's exact test. $\mathrm{p}<0.05$ was considered statistically significant.

\section{Study ethics}

The study protocol was approved by the local ethics committee. Verbal informed consent was obtained from the parents of the patients.

\section{RESULTS}

During the study period 2376 patients with mild TBI were admitted to our PED. Of these, 251 (10.6\%) had a head CT scan according to the PECARN decision rules, of whom 120 (47.8\%) had a positive initial head CT scan and underwent a second CT scan. After the exclusion of 1 patient with incomplete data, 2 with ventriculoperitoneal shunt, and 4 admitted more than 24 hours after trauma, the study population consisted of 113 patients.

The median age was 28 (IQR: 6.5-80) months, and $65(57.5 \%)$ of all patients were male. Fall (74.3\%) was the most common mechanism of injury, followed by struck by an object (12.4\%), pedestrian struck by vehicle (7.1\%), motor vehicle crash (5.3\%), and bicycle collision (0.9\%). On admission, 72 (63.7\%) of the patients were asymptomatic and 5 of the remaining 41 patients had more than one symptom. The symptoms were vomiting (41.3\%), loss of consciousness (34.8\%), amnesia (13\%), and headache (10.9\%). There was no physical examination finding in $54(47.8 \%)$ patients. Demographic and clinical characteristics of the two study groups are summarized in Table 1. 
Table 2. Initial and second head CT findings in the study groups

\begin{tabular}{llll}
\hline & Preverbal $(\mathbf{n}=\mathbf{4 4})$ & Verbal $(\mathbf{n}=\mathbf{6 9})$ & $\mathbf{p}$ \\
\hline Initial head CT findings, $\mathbf{n}(\%)$ & & & \\
Linear skull fracture & $35(70.0)$ & $50(61.7)$ & \\
SDH & $4(8.0)$ & $14(17.3)$ & \\
Contusion & $6(12.0)$ & $11(13.6)$ & 0.097 \\
SAH & $2(4.0)$ & $3(3.7)$ & \\
EDH & $1(2.0)$ & $3(3.7)$ & 0.244 \\
IPH & $1(2.0)$ & - & \\
Depressed skull fracture & $1(2.0)$ & & \\
Progression & $1(2.3)$ & $6(8.7)$ & $63(91.3)$ \\
$\quad$ No progression & $43(97.7)$ & \\
\hline CT: computed tomography; EDH: epidural hematoma; IPH: intraparenchymal hemorrhage; SAH: subarachnoid hemorrhage; SDH: subdural \\
hematoma
\end{tabular}

Table 3. Demographics and clinical findings of patients with progression in second head CT

\begin{tabular}{|c|c|c|c|c|c|}
\hline Age / Sex & Mechanism of injury & Admission symptom & Physical examination & Initial head CT finding & Second head CT finding \\
\hline 2 years / Male & Fall & Vomiting & $\begin{array}{l}\text { Scalp hematoma and } \\
\text { laceration }\end{array}$ & SDH & Increased size of SDH \\
\hline 2 years / Female & Fall & Vomiting & Scalp hematoma & Linear fracture & Linear fracture and IPH \\
\hline 10 years / Male & Fall & LOC & $\begin{array}{l}\text { Scalp hematoma and } \\
\text { laceration }\end{array}$ & Linear fracture and EDH & Increased size of EDH \\
\hline 2 years / Male & Fall & Vomiting & - & Linear fracture and SDH & Increased size of SDH \\
\hline 5 years / Male & Fall & Vomiting & - & Linear fracture and SDH & Increased size of SDH \\
\hline 5 months / Female & Fall & LOC & Scalp hematoma & Linear fracture and EDH & Increased size of EDH \\
\hline 10 years / Male & Fall & Headache & $\begin{array}{l}\text { Scalp hematoma and } \\
\text { laceration }\end{array}$ & Linear fracture & EDH \\
\hline
\end{tabular}

CT: computed tomography; EDH: epidural hematoma; IPH: intraparenchymal hemorrhage; LOC: loss of consciousness; SDH: subdural hematoma

The CT findings are summarized in Table 2. The initial head CT revealed a total of 131 lesions, of which $64.9 \%$ were linear skull fracture, $13.7 \% \mathrm{SDH}, 13 \%$ contusion, 3.8\% SAH, 3\% EDH, 0.8\% IPH, and 0.8\% depressed skull fracture. Medical treatment was not required based on the initial head CT findings. The mean time between the first and second scans was $11 \pm 2.5$ hours. Second head CT scans revealed progression in $7(6.2 \%)$ patients, who were subsequently hospitalized in the neurosurgical service but did not require medical treatment or neurosurgical intervention (Table 3).

\section{DISCUSSION AND CONCLUSION}

To our knowledge, the present study was one of the few studies investigating the diagnostic and clinical value of second head CT scans in a pediatric cohort with mild TBI. We found that second head CT scans revealed progression in $6.2 \%$ of the patients with at least one traumatic lesion initially. However, as hy- pothesized, in none of these patients the medical treatment or neurosurgical intervention was changed.

The literature contains reports of various progression rates, ranging from 5.7 to $48 \%$, in the use of repeated head CT in pediatric TBI (5,7-9,11-13,17-20). Almost all of these figures are higher compared to our results $(5,7-9,12,13,17,19)$. This could be attributed to the effects of different sample characteristics, including patient age, TBI severity, the indications for and time of ordering a second head CT scan, and contemporaneous trends in neurosurgical practice. Figg et al. reported a progression rate of $13 \%$ in 40 children with severe TBI, in whom most of the repeated CT use was within routine clinical practice (13). A study on moderate and severe pediatric TBI showed that a second head CT scan scheduled within 24 to 36 hours revealed progression in $27 \%$ and new lesions in $9 \%$ of the patients included (9). In a pediatric cohort with moderate and severe TBI, the progression rate was reported to be $23.8 \%$ overall and $10 \%$ in routinely repeated CT (19). As the researchers focused on moderate and se- 
vere pediatric TBI, these results could be explained by concerns about the neurological outcomes in critical patients. However, mild TBI is more common in children, and physicians should attempt to establish a balance between the contributions and detrimental effects of repeated head CT. From this point of view, Hollingworth et al. reported that the rates of worsening and new injury were respectively $13 \%$ and $17 \%$ in a large cohort that consisted of almost equally distributed cases of moderate-severe and mild pediatric TBI. In this study, second head CT scans revealed deterioration in $20 \%$ of the patients with mild TBI, but there was no data elucidating the reasons for the ordering of the scans (12). Similarly, Aziz et al. reported a progression rate of $21 \%$ in children with mild, moderate, and severe TBI, and $85 \%$ of repeated CT was due to neurological deterioration. They also reported that the rate of progression found in second CT scans performed routinely was $18 \%$ (17). These higher rates are expectable because the study samples included cases of moderate and severe TBI. The number of studies focusing on mild TBI only, in accordance with our study, is limited. Our results are supported by a singlecenter study on 120 cases of mild TBI, which reported a progression rate of $6.6 \%$ in routinely repeated head CT (11). However, our study is still different from previous studies as we evaluated children with mild TBI in two age groups. We found that (preverbal) children aged $<2$ years were more asymptomatic but more frequently had findings on physical examination compared with (verbal) children aged $\geq 2$ years; and contrary to expectations, in the preverbal group there was only one child with progression. Other important results of our study were about patients with progression; all children with progression were symptomatic at the time of admission and almost all of them were seen to have a linear fracture in the first head CT scan.

As for the requirement for medical and/or surgical treatment, low rates were reported even in children with moderate and severe TBI $(5,13,17)$. Hollingworth et al. concluded that only $1 \%$ of children with mild TBI needed neurosurgical intervention and all these patients showed decline in GCS scores (12). In a study on 47 critically injured children, $11 \%$ of the patients underwent surgery, but patients who underwent routinely repeated CT did not require neurosurgical in- tervention (14). Moreover, Bata et al. demonstrated that patients with mild TBI did not require subsequent intervention, even though the overall rates of medical and neurosurgical treatment were $18.3 \%$ and $7 \%$, respectively (5). In accordance with the literature, we found that routinely repeated CT led to no change in the management of patients with progressive traumatic lesions.

The main limitations of our study are the retrospective design and the lack of data on time between injury and initial head CT and on long-term neurological outcomes. As our study included a small sample of patients with mild TBI from a single center, our results may not be representative of all patients.

In conclusion, we found that the progression rate in routinely repeated CT was $6.2 \%$ in pediatric patients with mild TBI, although the lesion progression detected did not change the medical or surgical management. Nevertheless, prospective studies with larger cohorts are needed to determine the standards for repeated head CT.

\section{Conflict-of-Interest and Financial Disclosure}

The authors declare that they have no conflict of interest to disclose. The authors also declare that they did not receive any financial support for the study.

\section{REFERENCES}

1. Chen C, Peng J, Sribnick EA, Zhu M, Xiang H. Trend of age-adjusted rates of pediatric traumatic brain injury in U.S. emergency departments from 2006 to 2013. Int J Environ Res Public Health. 2018;15(6):1171.

2. Coulter IC, Forsyth RJ. Paediatric traumatic brain injury. Curr Opin Pediatr. 2019;31(6):769-74.

3. Capizzi A, Woo J, Verduzco-Gutierrez M. Traumatic brain injury: an overview of epidemiology, pathophysiology, and medical management. Med Clin North Am. 2020;104(2):213-38.

4. Kuppermann N, Holmes JF, Dayan PS, Hoyle JD Jr, Atabaki SM, Holubkov R, et al. Identification of children at very low risk of clinically-important brain injuries after head trauma: a prospective cohort study. Lancet. 2009;374(9696):1160-70.

5. Bata SC, Yung M. Role of routine repeat head imaging in paediatric traumatic brain injury. ANZ J Surg. 2014;84(6):438-41. 
6. Araki T, Yokota H, Morita A. Pediatric traumatic brain injury: characteristic features, diagnosis, and management. Neurol Med Chir. 2017;57(2):82-93.

7. Durham SR, Liu KC, Selden NR. Utility of serial computed tomography imaging in pediatric patients with head trauma. J Neurosurg. 2006;105(Suppl. 5):365-9.

8. Givner A, Gurney J, O’Connor D, Kassarjian A, Lamorte WW, Moulton S. Reimaging in pediatric neurotrauma: factors associated with progression of intracranial injury. J Pediatr Surg. 2002;37(3):381-5.

9. Tabori U, Kornecki A, Sofer S, Constantini S, Paret G, Beck R, et al. Repeat computed tomographic scan within 24-48 hours of admission in children with moderate and severe head trauma. Crit Care Med. 2000;28(3):840-4.

10. Dawson EC, Montgomery CP, Frim D, Koogler T. Is repeat head computed tomography necessary in children admitted with mild head injury and normal neurological exam? Pediatr Neurosurg. 2012;48(4):221-4.

11. Howe J, Fitzpatrick CM, Lakam DR, Gleisner A, Vane DW. Routine repeat brain computed tomography in all children with mild traumatic brain injury may result in unnecessary radiation exposure. J Trauma Acute Care Surg. 2014;76(2):292-5.

12. Hollingworth W, Vavilala MS, Jarvik JG, Chaudhry S, Johnston BD, Layman S, et al. The use of repeated head computed tomography in pediatric blunt head trauma: factors predicting new and worsening brain injury. Pediatr Crit Care Med. 2007;8(4):348-56.

13. Figg RE, Stouffer CW, Kolk WEV, Connors RH. Clinical efficacy of serial computed tomographic scanning in pediatric severe traumatic brain injury. Pediatr Surg Int. 2006;22(3):215-8.
14. Schnellinger MG, Reid S, Louie J. Are serial brain imaging scans required for children who have suffered acute intracranial injury secondary to blunt head trauma? Clin Pediatr. 2010;49(6):569-73.

15. Goodman TR, Mustafa A, Rowe E. Pediatric CT radiation exposure: where we were, and where we are now. Pediatr Radiol. 2019;49(4):469-78.

16. Ideguchi R, Yoshida K, Ohtsuru A, Takamura N, Tsuchida $\mathrm{T}$, Kimura $\mathrm{H}$, et al. The present state of radiation exposure from pediatric CT examinations in Japanwhat do we have to do? J Radiat Res. 2018;59(suppl. 2):ii130-6.

17. Aziz H, Rhee P, Pandit V, Ibrahim-Zada I, Kulvatunyou N, Wynne J, et al. Mild and moderate pediatric traumatic brain injury: replace routine repeat head computed tomography with neurologic examination. J Trauma Acute Care Surg. 2013;75(4):550-4.

18. Yilmaz H, Yilmaz O. Follow-up computed tomography requirement of pediatric head trauma patients with abnormal imaging findings. World Neurosurg. 2019;124:e764-8.

19. da Silva PS, Reis ME, Aguiar VE. Value of repeat cranial computed tomography in pediatric patients sustaining moderate to severe traumatic brain injury. J Trauma. 2008;65(6):1293-7.

20. Stein SC, Spettell CM. Delayed and progressive brain injury in children and adolescents with head trauma. Pediatr Neurosurg. 1995;23(6):299-304. 